\title{
Women and Poverty
}

Barbara C Gelpi, Nancy C M Hartsock, Clare Novak, and Myra Strober (eds) The University of Chicago Press, $1986, \$ 25.00 \mathrm{hb}, \$ 10.95 \mathrm{pb}$

Women and Poverty is a collection of essays, many of which originally appeared in the American journal Signs and have now been reissued as a book. The empirical social trend which underlines the book is the increasing impoverishment of women in the United States. As more American women, alone or with responsibility for children, have been forced to rely upon their own earnings or state benefits for income, they have come to represent more than 65 per cent of all persistently poor adults; one out of every three femaleheaded households was designated as poor in 1984. The theoretical preoccupation of the book is how women's poverty in the United States has been produced in the conjuncture of US welfare capitalism, patriarchy, and the liberal state. The essays also suggest that the liberal state can be used to produce welfare and employment policy that will improve women's position. While most of the essays concentrate on society, economy and politics in the United States in the 1980s, there are also pieces on women in Cuba, India and Kenya.

Two important essays, Ros Feldberg's 'Comparable Worth: Towards Theory and Practice in the United States' and Joan Smith's 'Paradox of Women's Poverty: Wage-earning Women and Economic Transformation' explore how the economy, understood as a capitalist economy which incorporates patriarchal power relations, generates women's poverty. These essays assign a role to both demand and supply in creating women's segregated low-wage work, and in different ways see women's segregated labour as created both in the family and in structure of employment itself.

Feldberg argues that the history of low wages for US women is the result of the incorporation of patriarchal gender relations into developing industrial capitalism. The political and industrial strength of craft unions forced capital to consolidate gender hierarchies of the family as features of the labour market, and women workers became confined to sex-segregated jobs paying low wages. Feldberg argues that while previously low-paid and unemployed women had access through marriage to the family wage commanded by male workers, changing household patterns in the current period have deprived many women of such resources.

Feldberg sees the comparable worth movement as having a theory and practice to deal with the historically established combination of women's segregated and devalued work. Comparable worth argues that women's work is paid so little because women labour within a tradition that has treated women as temporary and supplementary workers. Comparable worth implies 
that there is a value of labour that derives from the content of work, that this value can be determined, and that it ought to be the basis upon which labour is compensated; comparable worth suggests that compensation should be independent of the social characteristics of workers. She discusses how the theory and methods of comparable worth reveal anomalies in the relationship among wages, women and work and how they call into question the premises of neo-classical economic theory. In a section on the implications of comparable worth, Feldberg explores its possibilities and limits as a strategy for equality, discusses whether it divides or unites male and female paid workers, and analyses its relationship to legal questions of discrimination. In general her view is that comparable worth has considerable potential to begin to challenge gender hierarchy and the operation of the market.

Joan Smith's article focuses upon a particular economic sector in which many low-paid women workers are concentrated, the service sector. Smith argues that there has been a restructuring of the US economy towards the service sector, which now absorbs an increasing degree of personal expenditure, exhibits an increase in overall output, shows a constant differential in its rate of return, achieves high sales relative to numbers employed, and has shown a phenomenal growth in proportion of employment. This sector exhibits certain characteristics of employment, particularly a growing wage differential with manufacturing and a high rate of part-time employment. These employment conditions, in turn, are tied to two conditions of operation that distinguish service sector establishments: a low capital-labour ratio and the highly competitive nature of their business environment. High dependence upon labour leads to a general rise in overall wages costs at the same time that there is stronger than average downward pressure on prices. In this sector, capital accumulation occurs through reductions in wages and a rapid expansion of the labour force. She argues that the growth of the service sector therefore relies upon a work force that must continually be endowed with marginal characteristics.

While insisting that it is not the preferences of women that have created the growth in the service sector and its conditions of employment, Smith argues that the service sector has been dependent upon the availability of women workers. The restructuring of the economy towards the service sector with its particular mechanisms of capital accumulation has been predicated upon a supply of workers involved in non-market institutions. The set of arrangements characterising or assumed to characterise women's lives as nonwage workers have been incorporated into the very grounds of the service economy, though those social arrangements are changing rapidly. The paradox of women's employment in the service sector is, first, that women's labour has been the major contributor to growth, yet women continue to be marginalised, treated as though they are not independent wage labourers. Secondly, Smith points out that women have been redefining their relation- 
ships to men and breaking historic patterns of economic dependency. Yet most of the jobs they are able to find are predicated on continued dependence.

Another set of essays emphasises the contribution of America's particularly weak and dualistic welfare provision to women's poverty. These essays are keenly aware of how means-tested provisions for the 'undeserving poor', often women, contrast with insurance-based public and private welfare for those with well-paying and regular work, mainly men. Welfare provision thus reinforces labour market inequalities. Women's poverty is produced by a combination of a weak position in labour market and in the welfare state.

Deborah K Zinn and Rosemary C Sarri, in 'Turning the Clock Back on Public Welfare,' document the impact of changes in Aid to Families with Dependent Children (AFDC) policy under the Reagan Administration's 1981 Omnibus Budget Reconciliation Act (OBRA). Since its inception in 1935, AFDC has remained fundamentally unchanged as a major meanstested programme providing income to women who are sole heads of families. While liberalising trends in the 1960s led to an extension of AFDC benefits, OBRA has reduced eligibility for AFDC particularly among poor working women. Since certain other benefits, particularly Medicaid health insurance, are contingent upon AFDC eligibility, termination has had especially serious consequences. Based upon a study conducted in 1982, Zinn and Sarri find a rate of termination from AFDC benefits of 78 per cent among their sample, with termination due mainly to earned income being deemed too high; 24 per cent of terminated clients were forced to return to AFDC. The authors find that in fact while AFDC women are usually stigmatised as undeserving 'welfare recipients' rather than described as poor working women, most of their sample worked at low paying retail and service sector jobs and many worked full-time before termination. When left without AFDC, women attempted to find better jobs, though few were able to do so. Termination of AFDC benefits had serious consequences, depressing monthly income to well below the poverty level. Loss of income in turn created tremendous family strain, including instances when women were not able to put food on their tables to feed children, problems of child care, and crises of health and health care. The women studied did not have poor education, no attachment to work, and a large number of dependents as conservatives would argue. But squeezed between low earnings and few social benefits, few could meet the basic needs of their children.

Diana Pearce's essay 'Toil and Trouble: Women Workers and Unemployment Compensation' shows how the present system of unemployment compensation tends to support relatively privileged, disproportionately male, workers, simply increasing inequalities produced in the labour market. In the United States, unemployment insurance had as a central goal the restoration of 'regular', displaced workers to activity in the labour market; it traditionally 
pursued this objective through income support, job placement services, and retraining assistance. No equivalent assistance was developed for less regularly employed workers, who remained dependent upon stigmatised and penurious welfare. The 'regular' workers for whom the programme was designed were a group largely synonymous with male breadwinners; women were generally regarded as 'dependents' or 'secondary workers' and therefore judged ineligible.

Pearce argues that unemployment compensation programmes no longer overtly discriminate against women. But the terms of the programme discriminate structurally against women because of the difference in their labour market participation from that of the regularly employed male head of household whom the programme was designed to serve. Pearce then summarises the characteristics of women's employment and shows how unemployment insurance qualification requirements exclude women from benefits. She shows how earnings eligibility requirements, regulations regarding domestic quits, disqualification rules, pregnancy discrimination, sexual harassment, and requirements for availability, ability and willingness to work translate into a denial of benefits or disadvantaged status under Unemployment Insurance for women workers.

Several essays in the volume discuss possible political remedies for women's poverty. Elaine Zimmerman discusses the mobilising activities of the Women's Economic Agenda Project (WEAP). The opening account of WEAP's history is followed by excerpted testimony from the Northern California Hearings on the feminisation of poverty. WEAP, which includes among its members AFDC mothers, healthworkers, union members, old women, women of colour, lawyers, community organisers, academics, public policy specialists and homemakers, focuses upon publicising women's poverty and remedies, tied to a strategy of electoral mobilisation. In the Spring of 1983 WEAP's predecessor, the East Bay Women's Coalition worked with California state legislators to organise hearings and a public campaign on women's poverty. After the hearings the group continued to be interested in mobilising women voters to take advantage of the 'gender gap' - the reported tendency of women to take more 'liberal' positions on a variety of issues, including social issues. Through a democratic consultation process, the group drew up an economic agenda and continued to mobilise women around the issue of poverty.

Sheila Kammerman discusses appropriate policy rather than mobilisation. She bases her policy recommendations upon a cross-national study of public income transfer policies in eight advanced industrial countries; the study considered how various types of families, including mother-only families with young children, fared economically and what sorts of transfers they received. She finds women with young children dependent upon meanstested AFDC in the United States but regards reform of AFDC as an 
inadequate solution to women's poverty. Drawing upon the experience of other countries her policy solution suggests that it is necessary to acknowledge the dramatic change in women's roles in society and to view mothers as employable, assuring them job opportunities and training. She also argues that children must be guaranteed an adequate standard of living. She argues for a family or child allowance paid to all parents as a universal child benefit, advance child support payments such as exist in Sweden, entitlement to a housing allowance on a means-tested basis, health insurance for single mothers in work, improved maternity and parenting policy, and improved child care provision subsidies.

The outstanding essays collected in Women and Poverty vary in their mix of empirical material and theory. But every essay is informed by a combination of empirical material, often statistical, and analysis. Perhaps the most purely empirical essay is the report of the results from the Panel Study of Income Dynamics. But even this analysis is carefully framed by concepts drawn from the debate between the human capital school and its critics and the 'culture of poverty' theorists and their critics. On the other hand, Zillah Eisenstein's essay employs a particularly abstract and difficult form of capitalist-patriarchy theory with little reference to the particular and concrete. Even where many of the essays include empirical data and have been written some time ago, they raise analytic questions in such a way that prevents them being seriously dated. For example, there have been a number of developments with respect to comparable worth in the United States since Ros Feldberg wrote her essay, but it remains one of the best discussions of the general issues underlying comparable worth debates. Similarly, the 1984 Presidential elections seemed to contradict confident predictions that a gender gap would work against the re-election of Ronald Reagan; yet Barbara Nelson's essay remains a thoughtful discussion of women's marginality in the liberal-democratic US state.

Reflecting American politics, the book is haunted by the problem of political and social agency. The book has little to say, in the end, about how women's poverty might actually be eradicated, about which organisations or movements might be most effective. Barbara Nelson notes the absence of a working class political party directly tied to unions, and the low level of political activity in the United States. And while she seems to be calling for a change in political culture and the concept of citizenship, she is unable to discuss how that change might come about. Similarly, the WEAP project emphasises electoral mobilisation of poor women, but the report on its activities does not raise the issue of the nature of political parties' and candidates' commitment to poor women or how party agendas might be systematically altered.

Sheila Kammerman's policy proposals make some concessions to the limits of United States politics. For instance, she stops short of proposing a 
universal and comprehensive national health service. But it is difficult to see which constituted political actors in the United States in the 1980s might institute policies which emphasise universal family allowances and the other benefits she recommends. Discussion of the role of unions and their role in overcoming the continued segregation of women into low paid jobs is missing or underdeveloped in the volume. While in the United States at present it may be especially important to work outside of electoral processes and state institutions, organising and mobilising poor and working class women and their allies, the collection does not really emphasise this imperative.

Peggy Kahn, University of Michigan-Flint.

\section{On the Edge: a study of poverty and longterm unemployment in Northern Ireland}

Eileen Evason

CPAG, $1985,67 \mathrm{pp}, \mathfrak{£ 2} .95$

Two years after its publication, few reviews of this report have been published, yet many groups have taken up the information for educational purposes. The report draws together the latest research findings of a new study of poverty and unemployment - a survey of the unemployed in Derry city conducted in 1983-84. It shows that 'the poorest region in the UK is the worst place to try living on the poverty line'. Calabria in southern Italy is the only EEC region with worse poverty. On the Edge assesses the social security system in Northern Ireland and analyses information on key benefits whilst studying the data available relating to groups at risk of income deprivation.

At the outset Eileen Evason suggests that whilst Northern Ireland is still treated as separate and different, it is the case that in recent years many parts of Britain have been scarred by social disorder and experienced the effects of deindustrialisation. Given the apparent upsurge of interest in Britain in the connection between racism and social policy, this study deserves attention given the echoes of racism in the experience of Northern Ireland - housing allocation policy was at the centre of the events surrounding the onset of the conflict in the late 1960s. Rather than being seen as a separate case, it can be argued that Northern Ireland is a 'test case'. In terms of social policy, no other region in the UK so clearly demonstrates the diversity of ends which the social security system can serve. This study of social policies in Northern Ireland starkly shows the incredible potential contained within legislation for the integration or alienation of minorities. No other region demonstrates so sharply that the social security system can oversee and contain levels of need previously considered impossible - and then go on to implement more cuts! Above all: "no other region so effectively refutes the view that, over time, 